\title{
Sistem Informasi Tempat Kost Dikawasan Universitas Sam Ratulangi Manado
}

\author{
Lisnawati Riadi, Yaulie Deo. Y. Rindengan, Stanley D. S. Karouw \\ Teknik Informatika Universitas Sam Ratulangi Manado \\ Jl. Kampus UNSRAT Bahu, 95115 \\ lisnariadi@gmail.com,rindengan@unsrat.ac.id, stanley.karouw@unsrat.ac.id
}

\begin{abstract}
Abstrak - Dalam pengelolahan data dan informasi, kemajuan teknologi sangat memiliki peran penting untuk menunjang hasil yang akan di dapatkan nantinya, salah satunya dalam bidang pendidikan. Sebagai salah satu instansi perguruan tinggi negeri yang terkenal di Manado, Universitas Sam Ratulangi setiap tahunnya memiliki jumlah mahasiswa yang setiap tahunnya mengalami peningakatan dari segi jumlah mahasiswa yang berasal dari luar daerah maupun dalam daerah sendiri. Hal ini mengakibatkan mereka masih harus mencari tempat tinggal sementara untuk dijadikan domisili sementara selama menjalani masa studinya. Banyaknya tempat kost dikawasan Universitas Sam Ratulangi namun tidak banyak diketahui banyak orang, khusunya mahasiswa yang belum memiliki teman untuk bisa ditanyai mengenai daerah-daerah yang ada di kawasan kampus. Hal ini membuat mereka merasa kebinggungan dalam mencari tau dimana saja daerah-daerah tempat kost yang ada dikawasan kampus, atau hanya sekedar mendengar dari mulut ke mulut orang lain tentang dimana saja tempat kost yang ada dikawasan kampus.
\end{abstract}

Kata kunci: Unsrat, Kost, Sistem Informasi, Lokasi.

\section{PENDAHULUAN}

Teknologi dapat dikatakan sudah menjadi bagian penting dalam kehidupan manusia saat ini.Perkembangan teknologi yang semakin hari semakin maju membuat manusia lebih dimudahkan dalam menjalankan aktivitas kehidupannya. Dengan kata lain, manusia dan teknologi merupakan dua hal yang tidak bisa dipisahkan. Berkembangnya teknologi tentu saja tidak bisa dilepaskan dari peranan manusia yang terus berusaha untuk menciptakan teknologi-teknologi baru.Selain itu, perkembangan ilmu pengetahuan dan teknologi juga merupakan salah satu faktor yang membuat lahirnya teknologi-teknologi baru tersebut. Kebutuhan manusia akan teknologi membuat manusia terus berinovasi untuk mengembangkannya dalam berbagai bidang, salah satunya dalam dunia pendidikan.

Sebagai perguruan tinggi negeri yang tiap tahunnya memiliki jumlah mahasiswa pendatang baru yang mengalami peningkatan, hal ini mengakibatkan mereka harus mencari tempat tinggal untuk dijadikan domisili sementara selama menjalani masa studinya. Banyaknnya tempat kost dikawasan kampus namun belum banyak diketahui oleh banyak orang. Hal ini membuat mereka sangat kebinggungan hanya untuk sekedar mencari tau dimana saja wilayah-wilayah daerah tempat kost yang ada dikawasan kampus. Sehingga masih harus berkeliling hanya untuk sekedar mencari tau dimana saja tempat dan lokasi kost yang ada di kawasan kampus.

Hal inilah yang merupakan tujuan dari penelitian ini yaitu bagaimana admin membuat suatu sistem informasi tempat kost yang dapat yang ada di kawasan universitas Sam Ratulangi untuk memudahkan pengguna mencari informasi serta lokasi mengenai tempat kost, dan bagaimana membuat pemilik kost lebih mudah mempromosikan tempat kostnya secara cepat.

\section{A. Pengertian Sistem Informasi}

Sistem informasi dapat didefinisikan sebagai suatu sistem di dalam suatu organisasi yang merupakan kombinasi dari orang-orang, fasilitas, teknologi, media, prosedur-prosedur dan pengendalian yang di tujukan untuk mendapatkan jalur komunikasi penting, memproses tipe transakasi rutin tertentu, memberi sinyal kepada manajemen dan yang lainnya terhadap kejadian-kejadian internal dan eksternal yang penting dan menyediakan suatu dasar informasi untuk pengambilan keputusan yang cerdik [1]. B. Pengertian Sistem Informasi Kost

Sistem Informasi Kost adalah system yang menyediakan layanan informasi kost secara rinci beserta fasilitasnnya kepada pengguna, dengan tujuan untuk mengatasi masalah yang di hadapi oleh pengguna.Tempat kost merupakan suatu tempat tinggal yang disewakan kepada pihak lain dengan fasilitasfasilitas tertentu dengan harga yang lebih terjangkau dari pada di hotel/penginapan. Tempat kost lebih akrab digunakan sebagai domisili, karena kebanyakan tempat kost disewa dalam jangka waktu yang cukup lama dari pada hotel atau penginapan yang menggunakan hitungan hari. Biasanya alasan memilih tempat kost sebagai tempat tinggal adalah studi/kuliah dalam jangka pendek ataupun lama, biaya yang terjangkau dibandingkan dari pada ke hotel/penginapan, tempat kost sudah sangat banyak dan mudah dijangkau yaitu yang terdapat dilokasi kampus, perkantoran, sekolah, dll. Cara penyewaan yang bervariasi, bergantung kebutuhan. Perhari, perbulan, per enam bulan atau pertahun[2].

C. Sistem Informasi Geografis

Sistem Informasi Geografis (SIG) adalah sistem yang terdiri dari perangkat keras, perangkat lunak, data, manusia (brainware), organisasi dan lembaga yang digunakan untuk mengumpulkan, menyimpan, 
menganalisis, dan menyebarkan informasi - informasi mengenai daerah - daerah di permukan bumi [3].

Sistem Informasi Geografis/GIS (Geographic Information System) merupakan bentuk cara penyajian informasi terkait dengan objek berupa wilayah dalam bentuk informasi spatial (keruangan). SIG mempunyai kemampuan untuk menghubungkan berbagai data pada suatu titik tertentu di bumi, menggabungkannya, menganalisa dan akhirnya memetahkan hasilnya. Data yang diolah pada SIG adalah data spasial yaitu sebuah data yang berorientasi geografis dan merupakan lokasi yang memiliki sistem koordinat tertentu, sebagai dasar referensinya. Sehingga aplikasi SIG dapat menjawab beberapa pertanyaan seperti lokasi, kondisi, tren, pola dan pemodelan.

\section{METODOLOGI PENELITIAN}

Adapun metode pengembangan sistem yang digunakan pada penelitian ini yaitu metode Rapid Application Development (RAD). RAD atau pengembangan aplikasi cepat adalah pendekatan berorientasi objek untuk pengembangan sistem yang meliputi metode pengembangan serta perangkat lunak [4]. Melihat RAD sebagai metodologi pengembangan sistem yang berusaha untuk mengatasi perubahan persyaratan kebutuhan user dan merekomendasikan RAD untuk mengembangkan aplikasi berbasis web [5]. RAD merupakan model proses perangkat lunak yang menekankan pada daur pengembangan hidup yang singkat. RAD merupakan versi adaptasi cepat dari model waterfall, dengan menggunakan pendekatan konstruksi komponen [6].

Ada 4 tahapan yang harus dilakukan pada metodologi RAD yaitu sebagai berikut :

\section{1) Analisis Persyaratan}

Tahap ini bertujuan untuk mengidentifikasikan kebutuhan pengguna, spesifikasi sistem melalui observasi dan pengumpulan data yang dilakukan terhadap stakeholders, sehingga aplikasi yang akan dibuat akan sesuai dengan yang dibutuhkan oleh pengguna. Pada bagian ini menggunakan tools UML.

\section{2) Analisis Modelling}

Pada tahapan ini bertujuan untuk menganalisis sistem yangsedang berjalan dari semua kegiatan yang terjadi pada sistem. Pada tahap ini, ada 2 tools UML yaitu usecase diagram dan activity diagram yang berfungsi untuk menggambarkan proses yang terjadi dalam sistem yang sedang berjalan.

\section{3) DesainModelling}

Tahapan ini untuk melakukan perancangan sistem melalui analisis kebutuhan dan persyaratan dari pengguna yang telah dilakukan sebelumnya. Pada tahap ini tools UML yang digunakan yaitu usecase diagram, activitydiagram, dan sequence diagram. Sehingga diharapkan sistem yang dibuat akan sesuai.

\section{4) Konstruksi}

Tahap ini akan menunjukkan platform, hardware, software, batasan implementasi, dan pengujian aplikasi yang telah dibangun apakah sudah sesuai dengan kebutuhan users danspesifikasipersyaratan yang sebelumnya telah dianalisis. Bagian ini menggunakan tools UML.

\section{HASIL DAN PEMBAHASAN}

A. Tahap Analisis Persyaratan

Tahapini mengidentifikasikan layanan, batasan, dan obyektivitas dari sistem pengumpulan data yang dilakukan. Selain itu, fase analisis persyaratan juga bertujuan untuk mendefinisikan persyaratan pengguna dan sistem.

Komunikasidan perencanaan meliputi pembahasan mengenai rencana kerja, manajemen resiko dan manajemen kebutuhan Rencana kerja riset, rencana kerja riset dapat dilihat pada Gambar 1.

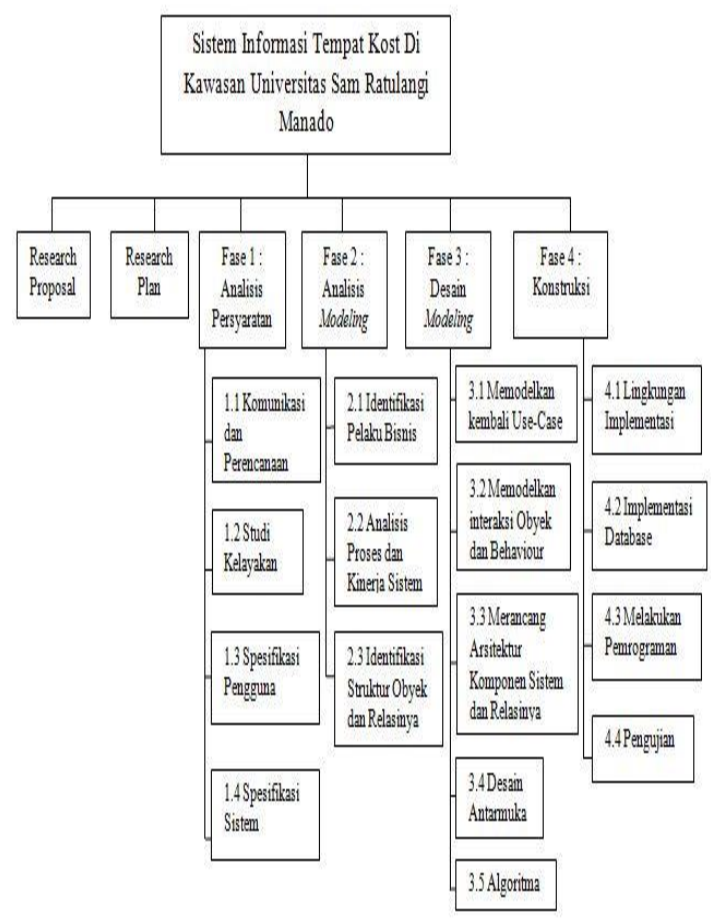

Gambar 1. Rencana Kerja Riset

\section{1) Manajemen Resiko}

Dalam setiap proyek, tentu sajadiperhadapkan dengan berbagai macam resiko, berikut adalah resiko-resiko yang mungkin terjadi dalam pengembangan aplikasi dapat dilihat pada tabel 1 .

\section{2) Spesifikasi Pengguna}

Tahap ini akan mengidentifikasi dan menetapkan kebutuhan pengguna. Tahap ini terbagi atas identifikasi target pengguna, pengumpulan dan pemrosesan data, identifikasi dan analisis masalah dan kesempatan, dan identifikasi prioritas dari kebutuhan pengguna.

\section{B. Tahap Analisa Modeling}

Fase ini menganalisa semua kegiatan dalam arsitektur secara keseluruhan dengan melibatkan indentifikasi dan deskripsi abstraksi sistem perangkat Lunak yang mendasar dan hubungan-hubungannya serta untuk meningkatkan pemahaman terhadap permasalahan terhadap permasalahan tanpa mempertimbangkan solusi teknis. 


\section{1) Mengidentifikasi Pelaku Bisnis}

Identifikasi para pelaku bisnis atau para pengguna aplikasi merupakan salah satu proses penting dalam pembuatan aplikasi sehingga para programmertau siapa saja yang akan menggunakan aplikasi yang akan dibuat. Dapat dilihat pada Tabel 2 merupakan daftar pelaku bisnis yang ada pada aplikasi yang akan di buat.

Tabel 1. Tabel Manajemen Resiko

\begin{tabular}{|c|c|c|c|c|}
\hline No. & Risk & Contigency & Cause & Effect \\
\hline 1. & $\begin{array}{l}\text { Perubahan } \\
\text { jadwal. }\end{array}$ & $\begin{array}{l}\text { Penyesuaian } \\
\text { jadwal } \\
\text { kembali. }\end{array}$ & $\begin{array}{l}\text { Keterla } \\
\text { mbatan. }\end{array}$ & $\begin{array}{l}\text { Waktu } \\
\text { lebih } \\
\text { lama. }\end{array}$ \\
\hline 2. & $\begin{array}{l}\text { Kesalahan } \\
\text { pemrogra } \\
\text { man. }\end{array}$ & $\begin{array}{l}\text { Perbaikan } \\
\text { kesalahan } \\
\text { pemrograma } \\
\text { n. }\end{array}$ & $\begin{array}{l}\text { Ketidak- } \\
\text { telitian. }\end{array}$ & $\begin{array}{l}\text { Keterlam } \\
\text { batan } \\
\text { dan } \\
\text { performa } \\
\text { yang } \\
\text { tidak } \\
\text { maksima } \\
\text { l. }\end{array}$ \\
\hline 3. & $\begin{array}{l}\text { Perubahan } \\
\text { persyarata } \\
\mathrm{n} \\
\text { pengguna. }\end{array}$ & $\begin{array}{l}\text { Pemrograma } \\
\text { n kembali. }\end{array}$ & $\begin{array}{l}\text { Keingina } \\
\mathrm{n} \text { user } \\
\text { yang } \\
\text { berubah- } \\
\text { ubah. }\end{array}$ & $\begin{array}{l}\text { Keterlam } \\
\text { batan } \\
\text { dan } \\
\text { performa } \\
\text { program } \\
\text { yang } \\
\text { tidak } \\
\text { maksima } \\
\text { l. }\end{array}$ \\
\hline 4. & $\begin{array}{l}\text { Kesalahan } \\
\text { analisis } \\
\text { sistem. }\end{array}$ & $\begin{array}{l}\text { Analisis } \\
\text { kembali } \\
\text { dan terjadi } \\
\text { perombakka } \\
\text { n desain. }\end{array}$ & $\begin{array}{l}\text { Keingina } \\
\mathrm{n} \text { user } \\
\text { yang } \\
\text { tidak } \\
\text { teridentif } \\
\text { ikasi } \\
\text { dengan } \\
\text { baik }\end{array}$ & $\begin{array}{l}\text { Perubaha } \\
\text { n fitur. }\end{array}$ \\
\hline
\end{tabular}

Tabel 2. Daftar Aktor Beserta Tugas dan Tanggung Jawabnya

\begin{tabular}{ll}
\hline \multicolumn{1}{c}{ Aktor } & Tugas dan Tanggung Jawab \\
\hline Admin & $\begin{array}{c}\text { 1. Mengatur database berupa } \\
\text { penambahan data,edit data, dan } \\
\text { hapus data kost. }\end{array}$ \\
& $\begin{array}{l}\text { 2. Sebagai sumber informasi bagi } \\
\text { user }\end{array}$ \\
& $\begin{array}{l}\text { 1. Melakukan registrasi member } \\
\text { kost. }\end{array}$ \\
$\begin{array}{l}\text { User } \\
\text { (Pemilik Kost) }\end{array}$ & $\begin{array}{l}\text { 2. Melihat informasi tempat kost. } \\
\text { User } \\
\text { (Pencari Kost) }\end{array}$ \\
$\begin{array}{l}\text { 2. Melakukan pemesanan tempat } \\
\text { kost }\end{array}$ \\
\hline
\end{tabular}

2) Use Case Diagram

Use case diagram dirancang untuk menunjukkan secara umum fungsi dan tanggung jawab masing- masing aktor sistem dalam Sistem Informasi Tempat Kost Dikawasan Universitas Sam Ratulangi Manado beserta Sub-systen di dalamnya yang akan dirancang. Use case terdiri dari Use case diagram Sistem Informasi Tempat Kost Dikawasan Unsrat dapat dilihat pada gambar dibawah ini :

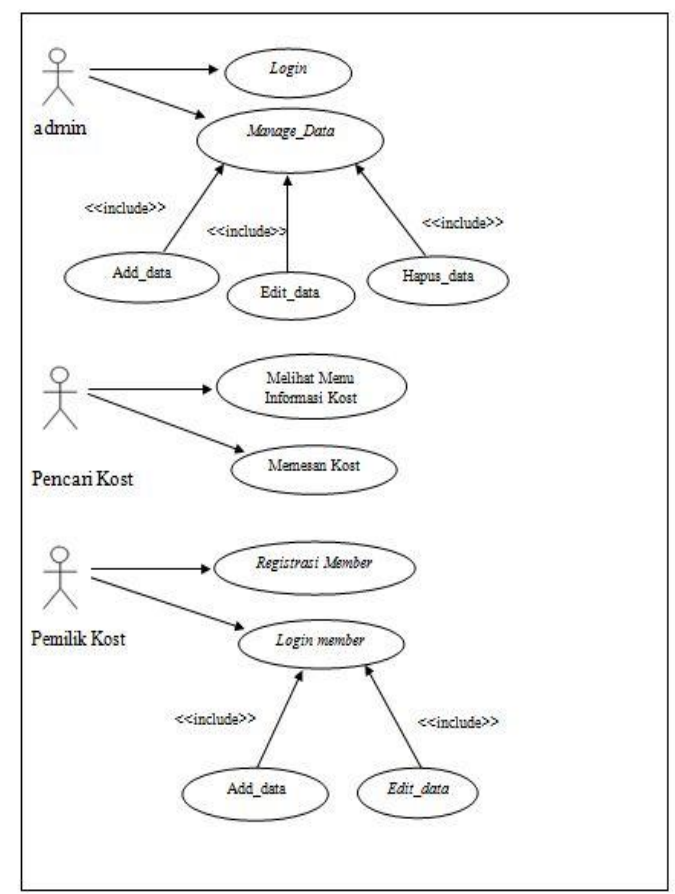

Gambar 2. Use Case Diagram Sistem Informasi Tempat Kost Dikawasan Universias Sam Ratulangi Manado

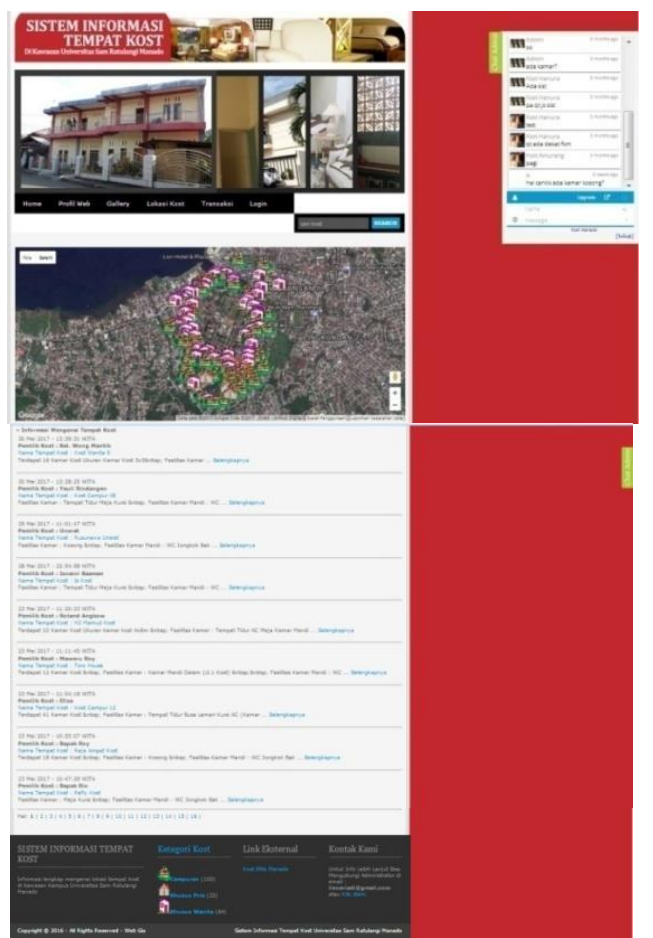

Gambar 3. Halaman Awal Sistem Informasi Tempat Kost Dikawasan UNSRAT Manado 
Pada Gambar 3. Merupakan halaman awal sistem terdapat berbagai menu dari Sistem Informasi Tempat Kost Dikawasan Universitas Sam Ratulangi Manado.Pada Pada halaman awal sistem terdapat tampilan peta lokasi seluruh tempat-tempat kost yang ada di kawasan Universitas Sam Ratulangi Manado, risent update informasi kost, dan live chat antara pencari kost dengan admin dan member kost atau pemilik kost.

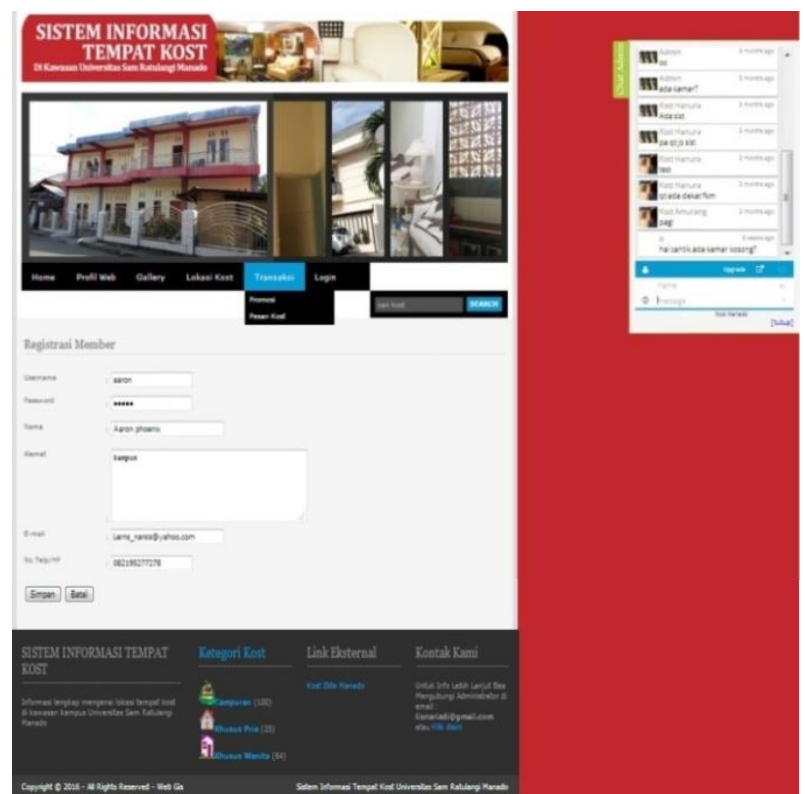

Gambar 4. Halaman Registrasi Member Kost

Pada Gambar 4 Merupakan sub-menu Transaksi yang terdapat registrasi member kost seperti pada Gambar 4. Pada halaman ini user dapat melakukan registrasi member untuk bisa mendapatkan username dan password, agar user dapat mempromosikan tempat kost miliknya.

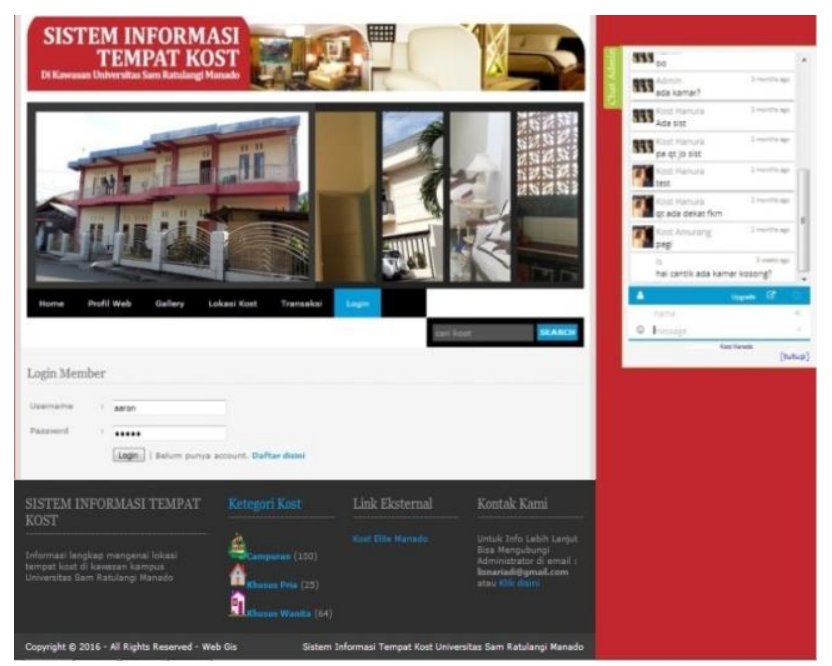

Gambar 5. Halaman Login Member

Pada Gambar 5 merupakan halamanlogin memberini user dapat melakukan registrasi member untuk bisa mendapatkan username dan password, agar user dapat mempromosikan tempat kost miliknya. Setelah melakukan registrasi member, pemilik kost dapat melakukan login member untuk bisa masuk ke halaman user seperti pada gambar 5 .

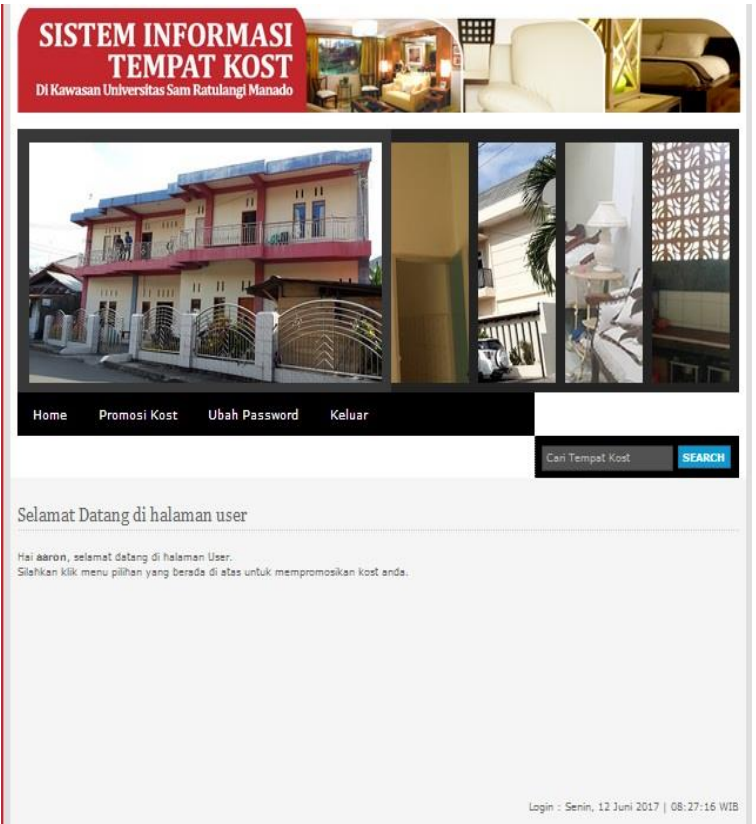

Gambar 6. Halaman Selamat Datang di User

Gambar 6 merupakan halaman Selamat Datang di User. Bila user berhasil melakukan login member dan masuk ke dalama halaman user, maka terdapat pilihan menu yang ada di halaman user seperti promosi kost, ganti password dan keluar dari halaman tersebut seperti pada gambar 6 .

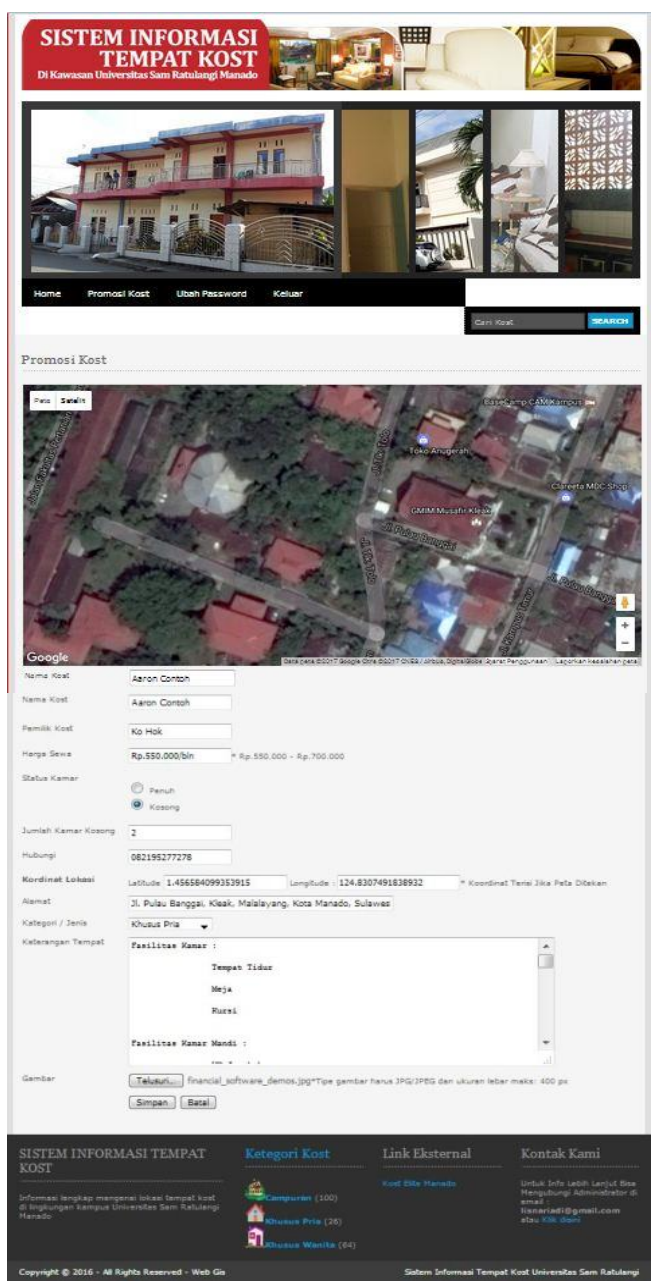

Gambar 7. Tampilan Menu Promosi Kost 
Pada Gambar 7 merupakan Menu Pomosi Kost yang ada pada halaman user. Disini pemilik kost dapat mempromosikan tempat kostnya yang ada di kawasan kampus.

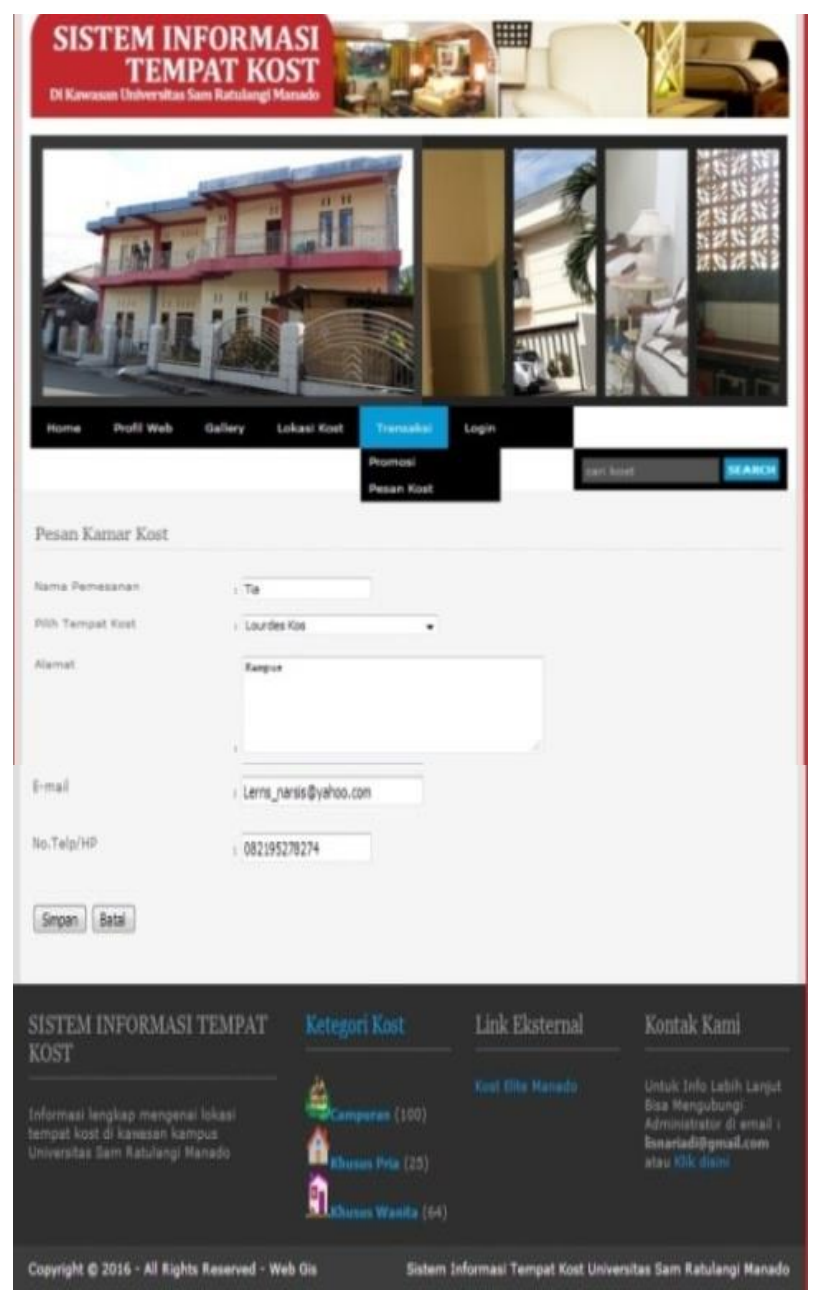

Gambar 8. Menu Pesan Kamar Kost

Pada Gambar 8 merupakan Menu Pesan Kamar Kost yang terdapat pada pada sub menu transaksi.

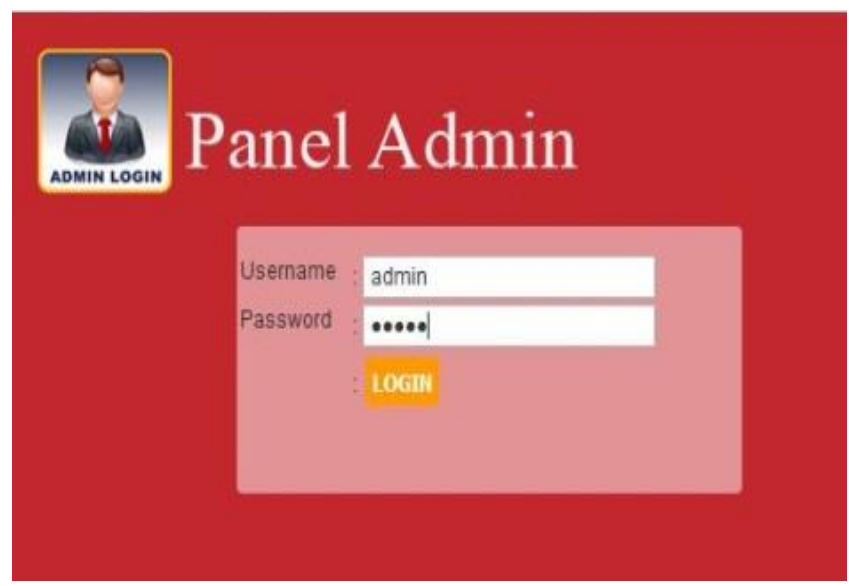

Gambar 9. Halaman Login Admin Sistem Informasi Tempat Kost

Pada Gambar 9. Merupakan halaman login khusus untuk admin Sistem Informasi Tempat Kost Dikawasan Universitas Sam Ratulangi Manado.

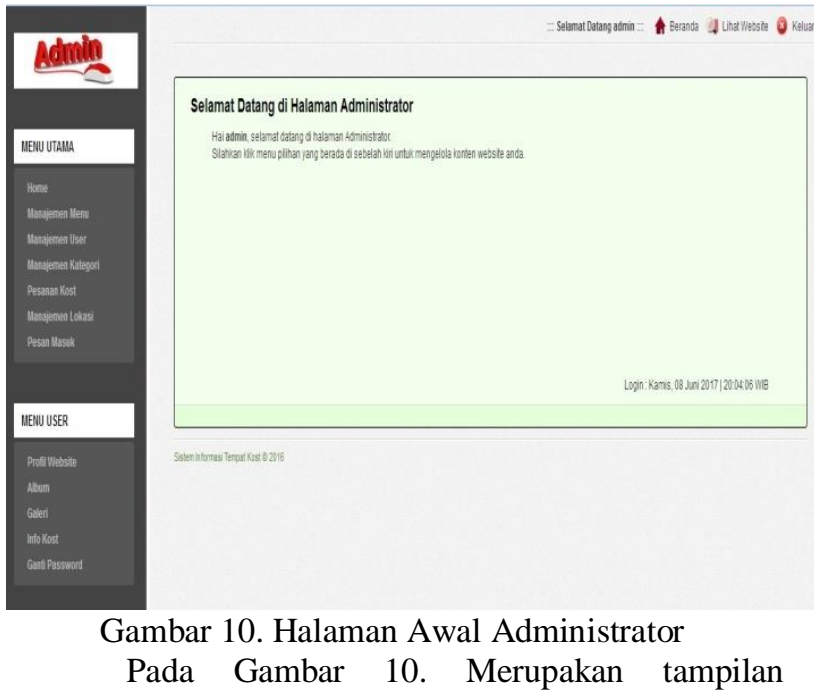
halaman awal admin Sistem Informasi Tempat Kost setelah admin melakukan login seperti pada gambar 9. Dalam halaman ini admin Sistem Informasi Kost bisa dapat melakukan berbagai kegiatan seperti menambah data kost, edit data dan hapus data kost.

\section{A. Kesimpulan}

\section{PENUTUP}

Berdasarkan pembahasan pada bab-bab sebelumnya, maka dapat ditarik kesimpulan sebagai berikut:

1) Sistem informasi tempat kost dikawasan Universitas Sam Ratulangi Manado telah berhasil dibuat. Sistem ini dilengkapi dengan peta lokasi dari tempat-tempat kost yang ada dikawasan kampus dan selain itu penulis juga menyediakan menu untuk memesan tempat kost sesuai yang diinginkan.

2) Dengan adanya sistem ini akan lebih memudahkan pemilik kost dalam memberikan informasi tentang kostnya yang ada dikawasan kampus.

\section{B. Saran}

Apabila untuk kedepannya ada yang ingin mengembangkan penelitian ini lebih lanjut, disarankan untuk menambahkan menu transaksi keuangan penyewaan tempat kost.

\section{DAFTAR REFERENSI}

[1] Jogiyanto Hartono, H.MM. Sistem Informasi. PT.Wahana Komputer. Semarang. 1999.

[2] Bakti, Abidin. Sistem Informasi Rumah Kost Online Berbasis Web Dan Messaging. Jurusan Teknik Informatika. Politeknik Elektronika Negeri Institut Teknologi Sepuluh November. Surabaya. 2012.

[3] Oktafia Dian. Sistem Informasi Geografis (SIG).Universitas Guandarma. 2005.

[4] Kendall.Analisis \& Perancangan sistem. Jakarta. 2008.

[5] Kendall and Kendall. System Analysis and Design $7^{\text {th }}$ ed. Pearson Prentice Hall. 2007.

[6] Pressman.Software Engineering, A Practitioner's Approach,McGrawHill.Singapura. 2005. 


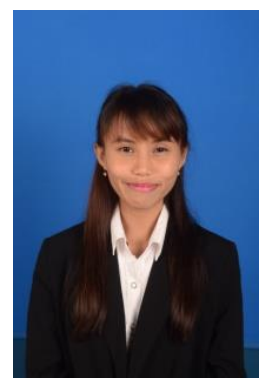

Sekilas dari penulis dengan nama lengkap Lisnawati Riadi, lahir di Manado Provinsi Sulawesi Utara, pada tanggal 20 September 1993. Anak tunggal dengan pendidikan TK Kartika VII-18 Ranomut selanjutnya penulis melanjutkan pendidikan ke Sekolah Dasar Negeri 30 Manado.Penulis lalu melanjutkan ke Sekolah Menengah

Pertama Negeri 2Manado.Lalu ke SMA Negeri 4 Manado.Pada tahun 2011 melanjutkanke Perguruan Tinggi di Universitas Sam Ratulangi dengan mengambil Jurusan Teknik Informatika. Pada Tahun 2016 bulan Mei, penulis membuat Skripsi demi memenuhi syarat Sarjana (S1) dengan penelitian berjudul Sistem Informasi Tempat Kost Dikawasan Universitas Sam Ratulangi Manadoyang dibimbing oleh dua dosen pembimbing yaitu Yaulie Deo. Y. Rindengan, ST, MM, MSc dan Stanley D. S. Karouw, ST., MTI. Penulis dinyatakan lulus dari Program Studi Teknik Informatika Jurusan Elektro Universitas Sam Ratulangi Manado pada tanggal 20 Juni 2017. 